Original Contribution

\title{
ECONOMIC ANALYSIS OF ON-FARM TRIAL OF DROUGHT TOLERANT MAIZE IN KWARA STATE NIGERIA: A GENDER APPROACH
}

\author{
O. E. Ayinde ${ }^{1 *}$, T. Abdoulaye ${ }^{2}$, F. O. Takim ${ }^{3}$, A. O. Oloyede ${ }^{1}$, F. A. Bankole ${ }^{3}$ \\ ${ }^{1}$ Department of Agricultural Economics and Farm Management, University of Ilorin, Ilorin, Nigeria \\ ${ }^{2}$ International Institute of Tropical Agriculture (IITA), Ibadan, Nigeria \\ ${ }^{3}$ Department of Agronomy, University of Ilorin, Ilorin, Nigeria
}

\begin{abstract}
This study analyzed the profitability of on-farm trial of Drought Tolerant (DT) Maize in Kwara State Nigeria using a gendered innovation approach. A Two-stage stratified sampling technique was used. The primary data for the study were collected through the use of well-structured questionnaires administered to forty (40) women farmers in an on-farm trial of the DT maize variety. The analytical tools used include Descriptive statistics, Ranking and Farm budgeting analysis. The result of the analysis showed that the women farmers were all married with only $10 \%$ of the farmers having no formal education and of an average age of 41 years. The result of varietal preference differs in some locations. The women farmers ranked the DT maize variety as the best at two of the locations. The profitability of the maize varieties also differs per location with the DT maize varieties having the highest profit at three locations. It is therefore recommended that women farmers should be involved in the varietal selection procedure so as to facilitate easy adoption of the drought tolerant maize. This will ensure that the women farmers' needs and preferences are incorporated in the development of agricultural innovations.
\end{abstract}

Key words: Women, Innovation, Farm budgeting, Drought Tolerant Maize, Preference

\section{INTRODUCTION}

Maize (Zea mays L.) is one of the most important cereal crops in Nigeria. Nigeria alone produces about $43 \%$ of maize grown in West Africa (1). The crop is grown virtually in all the agro-ecological zones of the country. It is a gender friendly crop cultivated by both men and women farmers. Although maize production has increased in Nigeria with a production volume that rose from 1,100,000 tons in 1980 to more than seven million tons in 2007-2008 (2). The increase was attributed to expansion of areas cultivated with maize, introduction of better performing varieties and availability of fertilizer at highly subsidized prices than any improvement in maize yield (1, $3,2)$. Average maize yields have stagnated around 1.5 tons per hectare, significantly below the world average of 5 tons per hectare (4). Regier (5) indicated that abiotic stress caused primarily by fluctuations in temperature, rainfall, salinity, sunlight, and

\footnotetext{
*Correspondence to: $O$. E. Ayinde, Department of Agricultural Economics and Farm Management, University of Ilorin, Ilorin, Nigeria, opeayinde@gmail.com
}

wind can significantly reduce yield and are already challenges faced by many farmers in Sub-Saharan Africa. Drought, which has been recognized as one of the most costly threats to agriculture accounts for an average annual production losses of 20 million metric tons of maize in tropical areas (6). Many farmers in Sub-Saharan Africa either find irrigation to be cost-prohibitive or lack the necessary groundwater resources.

Maize can be bred to be more tolerant of abiotic stress. Genetically Modified (GM) technology has led to the discovery of certain genes which control certain operations in the plant, allowing it to perform even under drought or heat stress (7). Empirical evidence $(6,5)$ have shown that the use of Drought Tolerant (DT) maize varieties stabilize maize yields in drought prone ecologies and also increase land area cultivated to maize. For example, insertions of drought tolerant genes into maize have generated 10-23 percent higher yields under drought stress compared to traditional maize varieties (8). The drought tolerant maize varieties are especially targeted towards the poor and resource limited farming 
AYINDE O. E., et al.

household in the more marginal rain-fed agricultural areas. The International Institute of Tropical Agriculture (IITA) and CIMMYT has been the leading force in Drought Tolerant maize variety research in Nigeria. Since the inception of the Drought Tolerant Maize for Africa (DTMA) project activities in the country in 2007 cropping season, the best four (4) entries within each of the early and intermediate/late maturing DT varieties, which have demonstrated superiority for grain yield, have been selected annually for testing under farmer's growing conditions in the Northern and Southern Guinea Savanna zones of the country.

Women play significant role in contributing to the rural economy, yet they consistently have less access than men to the resources and opportunities they need to be more productive (9). Women on the average comprise of about 43 percent of the agricultural labour force in developing countries. Women also contribute between 40 and 65 percent of labour hours spent in agricultural production and processing and also undertake 60 to 90 percent of the rural agricultural product marketing, thus providing more than two thirds of the workforce in agriculture (10). The female-headed households cultivate smaller land; have poor access to credit services and capital and agricultural innovations with only 18 percent of rural plots being managed by female farmers. The distribution of responsibilities and resources between men and women are socially determined. Consequently, women fall victim to several barriers that diminish their agricultural productivity. For example, legal structures or cultural norms often prevent them from accessing and owing a farmland. This situation probably brings about the perception that women are not natural farmers leaving the men as the decision makers when it comes to resource utilization and women as marginal farmers. This therefore, leads to bias of service delivery towards men (10).

Despite women's role as key players in the agricultural sector, men have continued to dominate farm decision making, which could be counter-productive, due to conflicts that arises when women are not involved in the decision process (11).

Rural women are responsible for up to 60 to 80 percent of food production in developing countries, yet they are often underestimated and overlooked in technological innovation, policies and strategies (10). However agricultural technological innovations can be turned into opportunities to boost women's production and profitability and improve their household food security and quality of life and family, if gendered dynamic of innovation is well examined.

Due to economic issues, women have their own plots in which they manage. However, there is usually no specification on the type of agricultural innovation women farmers prefer and adopt. Furthermore, little is known about the profitability of the women farmers'production. The general objective is to analyze the preference of women farmers' in innovation system using the DT maize variety production in Kwara state as a case study. The specific objectives are to: identify the women farmers'preference and evaluate the profitability of the women farmers in new variety production. Women's integration in the use of agricultural technological innovation such as DT maize has to be examined to enhance gender equity in the use of agricultural technology (DT maize) and to determine the women preference in agricultural technological innovation, so as to improve adoption and strengthen the agricultural sector of the nation and to raise the standard of living of the people. Women's role in agricultural production is essential for nutritional status of the families as well as the generation of income. Consequently, a genderbalanced agricultural growth is critical to successful agricultural innovation system and in turn to increases food security, reduces poverty and attains the Millennium Development Goals (MDG) (12).

\section{LITERATURE REVIEW}

\section{Women and Agricultural Innovation}

Technological innovation is the process through which new (or improved) technologies are developed and brought into widespread use (13). Sagar (13) further stated that innovation can be thought of as being composed of research, development, demonstration, and dissemination which allows for various interconnections and feedback loops between the stages. According to Rogers (14) the technology is passed from its source to the end users through a medium (e.g. news media, opinion leaders, on-farm or on-station demonstrations, and farmers' field days) and its diffusion to potential users is dependent to a great extent on the personal attributes of the individual user. However, much research has focused on the adopter in order to determine what variables might contribute to the adoption or rejection of an innovation.

New technologies and their adoption by farmers are important drivers in maintaining 
agricultural competitiveness in the global world (15). Agricultural innovation has led to impressive yield gains and lower food prices over the past century (16). More recently, the connection between innovation and gender has attracted more interest among policymakers, researchers and business leaders (17). This is necessary because innovation impacts positively on agricultural performance and growth. Women supply about 80 percent of the agricultural production which comes from small farmers in Africa. However, rural women in Africa constitute the highest illiteracy and poverty rates despite the important roles they play in agricultural economies (18). Their contribution in the agricultural sector is often concealed due to social barriers and gender bias. Government programs often than not fail to focus on women in agriculture. Also, agricultural research often focuses on technological innovations but seldom consider social disparities or differing effects on men and women (19).

Innovation that ignores gender inequality can be limited in its impact and may even worsen the poverty, workload and wellbeing of poor rural women and their families $(20,18)$. The vast majority of literature confirms that women are just as efficient as men and would achieve the same yields if they had equal access to productive resources and services. Most of the studies found that differences in yields were attributable to differences in input levels, suggesting that reallocating inputs from male to female plots can increase overall household output ( 9).

Beuchelt \& Badstue (19) indicated that if rural women in developing countries had the same access to land which could lift 100 to 150 million people out of hunger. The study emphasized that the reduction of gender disparities and the empowerment of women leads to better food and nutrition security for households and significantly strengthens other development outcomes such as child education. Yet, more than 1.1 billion women worldwide do not have equal access to land, inputs and extension.

In a 2013 working paper, "Gender and Agriculture: Inefficiencies, Segregation, and Low Productivity Traps, "Croppenstedt, Goldstein, and Rosas argued that women are caught in a low productivity trap that limits their access to agricultural resources and prevents them from increasing their yields.

Two flagship reports-the Food and Agriculture Organization's (FAO's) State of
Food and Agriculture 2010-2011 and the World Bank's World Development Report 2012-turn their attention to gender issues in agriculture. Emphasizing women's contributions to agriculture in developing countries, The State of Food and Agriculture 2010-2011 highlights the need to close the gender gap in access to agricultural resources, education, extension, financial services, and labor markets; to invest in labor-saving and productivity-enhancing technologies and infrastructure to free women's time for more productive activities; and to facilitate women's participation in flexible, efficient, and fair rural labor markets. If women had the same access to productive resources as men, they could increase yields on their farms by 20-30 percent. This could raise total agricultural output in developing countries by 2.5-4 percent.

The World Development Report 2012 stresses that gender equality can lead to productivity gains, that women's increased control of household resources can improve outcomes for the next generation, and that empowering women as economic, social, and political actors can result in more representative decision making. The report also identifies areas where policy can help close the gender gap: equalizing access to economic opportunities and reducing productivity gaps between women and men; giving women a stronger voice in households and societies; and limiting the transmission of gender inequality across generations. Closing the gender gap in agriculture through agricultural technological innovation would generate significant gains for the agriculture sector and for society.

\section{METHODOLOGY}

\section{Area of study}

The study was conducted in Kwara State, Nigeria. Women On-farm trial activities were conducted in the five villages within the state by the DTMA team. The villages include Omupo, Lajiki, Isanlu Isin, Arandun and Amodu. Women groups were formed in each of these villages making a total of five groups. Each group consists of minimum of ten members (contact farmers) and maximum of twenty members. Four (4) drought tolerant (DT) open pollinated varieties (OPVs) and two (2) drought tolerant (DT) hybrids of maize were tested in women farmers' fields using onfarm approach through the women groups. The two hybrids were only tested at Lajiki village while the OPVs were tested at the remaining four villages. The fields were managed by the women farmers under the supervision of the 
AYINDE O. E., et al.

DTMA team in the state. The on-farm trials allowed the use of the farmers own variety (for comparison purpose), planted alongside the DT varieties, but distinguished by sign post for each variety for easy identification of the varieties.

The sampling technique consists of a two stage stratified sampling. At the first stage, four women farmer groups were selected. The second stage involved a random selection of 10 women farmer per group per location (village). The total number of farmers selected was forty (40).

\section{Analytical Technique}

Data collected from the trials were analyzed. The analytical techniques used include descriptive statistic, ranking method and farm budgeting tool. Descriptive statistic such as frequency, averages, mode, mean and ranking technique which involved the use of a 3-Likert scale to analyze the socioeconomic characteristics of the women farmer and the women farmers' preference scores in the study area. Farm budgeting analysis was used to analyze the profitability of the DT maize varieties in the study area.

\section{Farm Budgeting Analysis}

The Gross margin analysis was used. Input quantities, factor prices, physical output and gross returns were used. Since the fixed cost constitutes a negligible portion of the total costs of production, the gross margin analysis was employed and used. It is given as:

$\mathrm{GM}_{\mathrm{j}}=\mathrm{TR}_{\mathrm{j}}-\mathrm{TVC}_{\mathrm{j}}$

Where $\mathrm{GM}_{\mathrm{i}}=$ Gross Margin ( $\$ /$ ha)

$\mathrm{TR}_{\mathrm{j}}=$ Total Revenue ( $\left.\$ / \mathrm{ha}\right)$

$\mathrm{TVC}_{\mathrm{j}}=$ Total Variable Cost $(\AA / \mathrm{ha})$

Average rate of returns (ARR) was also obtained. This was done by dividing total gross margin (GM) by the total cost of production per hectare, multiplied by 100 . The implicit form is shown below

Where; TR and TVC are as defined earlier.

\section{RESULTS AND DISCUSSION}

Socio-economic Characteristics of Women Farmers

The socio-economic profile of the women farmers is presented in Table 1. The result of the analysis revealed that the average age of farmers in the study area is 41years with the oldest being 65years and the youngest 20years old. This implies that the women farmers are experienced in farming activities. About $10 \%$ of the female farmers were not educated. All the women farmers were married. The female farmers had an average farm size of 1.92 hectares. This implies that the female are less privileged to inputs and less involved in decision making process.

Table 1. Socio economic Characteristics of Women Farmers

Variables Frequency Percentage

\begin{tabular}{lll}
\hline $\begin{array}{l}\text { Age } \\
<29 \text { years }\end{array}$ & 11 & 27.5 \\
$30-39$ years & 10 & 25.0 \\
$40-49$ years & 10 & 25.0 \\
$50-59$ years & 9 & 17.5 \\
60 and above & 2 & 5 \\
Total & 40 & 100
\end{tabular}

Mean age

Marital Status

$\begin{array}{lll}\text { Single } & 0 & 0 \\ \text { Married } & 40 & 100 \\ \text { Total } & 40 & 100\end{array}$

Level of Education

No Formal Education $\quad 4 \quad 10$

Primary Education $\quad 21 \quad 52.5$

Secondary Education $\quad 10 \quad 25$

$\begin{array}{lll}\text { Tertiary Education } & 5 & 12.5\end{array}$

$\begin{array}{lll}\text { Total } & 40 & 100\end{array}$

Farm size

$\begin{array}{lll}1-5 & 40 & 100\end{array}$

6-10 00

Mean $\quad 1.92$

Source: Data collection 2014

\section{Women Farmer Variety Preference}

The result of the women farmer varietal preference is presented in Table $\mathbf{2}$. The women farmers at Isanlu Isin preferred the farmers'variety than the other two varieties. This could be as a result of the yellow colour of seed of the farmers' variety. The result for Lajiki showed that the women preferred the M1124-31 variety the most. The variety was also yellow in colour. The women group at Arandun also preferred the farmers' variety than the others. This is also due to the fact that the farmers' variety was yellow in color and 
AYINDE O. E., et al.

had bigger cobs. The result for Omupo showed that the women preferred the 2010TZE-Y-DTSTR variety. The farmers preferred the variety because it was an improved variety and they were familiar with some DT varieties. This implies that the seed colour is an important factor in the adoption of improved maize variety.

Table 2. Women Farmer variety Preference Result

\begin{tabular}{llllll}
\hline Village & Variety & $\begin{array}{l}\text { Low Preference } \\
(\mathbf{1})\end{array}$ & $\begin{array}{l}\text { Medium } \\
\text { Preference (2) }\end{array}$ & $\begin{array}{l}\text { High Preference } \\
(\mathbf{3})\end{array}$ & Rank \\
\hline Isanlu Isin & 2008SYN EE -W - DT-STR & 9 & 1 & 0 & $3^{\text {rd }}$ \\
& 2013TZEE-WDT STR & 2 & 3 & 5 & $2^{\text {nd }}$ \\
& Farmer & 0 & 2 & 8 & $1^{\text {st }}$ \\
\hline Lajiki & MI026-13 & 4 & 5 & 1 & $3^{\text {rd }}$ \\
& MII24-31 & 0 & 2 & 8 & $1^{\text {st }}$ \\
& Farmer & 2 & 3 & 5 & $2^{\text {nd }}$ \\
\hline \multirow{2}{*}{ Arandun } & 2010TZE-Y-DT-STR & 6 & 2 & 2 & $3^{\text {rd }}$ \\
& 2009DTE-Y-STR & 1 & 2 & 7 & $2^{\text {nd }}$ \\
& Farmer & 0 & 1 & 9 & $1^{\text {st }}$ \\
\hline Omupo & 2010TZE-Y-DT-STR & 0 & 2 & 8 & $1^{\text {st }}$ \\
& 2009DTE-Y-STR & 2 & 3 & 5 & $2^{\text {nd }}$ \\
& Farmer & 8 & 2 & 0 & $3^{\text {rd }}$ \\
\hline
\end{tabular}

Source: Data collection 2014

Table 3. Profitability of the On-farm Trial of Women Farmer Group

\begin{tabular}{lllllllll}
\hline Village & Variety & $\begin{array}{l}\text { Yield } \\
\text { (kg/ } \\
\text { ha) }\end{array}$ & $\begin{array}{l}\text { Fertilizer } \\
\text { costs } \\
\text { (Naira) }\end{array}$ & $\begin{array}{l}\text { Other } \\
\text { expenses } \\
\text { (Naira) }\end{array}$ & $\begin{array}{l}\text { Total } \\
\text { cost } \\
\text { (Naira) }\end{array}$ & $\begin{array}{l}\text { Gross } \\
\text { returns } \\
\text { (Naira) }\end{array}$ & $\begin{array}{l}\text { Profit } \\
\text { (Naira) }\end{array}$ & $\begin{array}{l}\text { Return to } \\
\text { Investment }\end{array}$ \\
\hline $\begin{array}{l}\text { Isanlu } \\
\text { Isin }\end{array}$ & $\begin{array}{l}\text { 2008SYN EE - } \\
\text { W - DT-STR }\end{array}$ & 2,016 & 36,000 & 17600 & 53600 & 90720 & 37120 & 0.693 \\
& $\begin{array}{l}\text { 2013TZEE- } \\
\text { WDT STR }\end{array}$ & 2,971 & 36,000 & 17600 & 53600 & 133695 & 80095 & 1.494 \\
& Farmer & 2,717 & 36,000 & 17600 & 53600 & 122265 & 68665 & 1.281 \\
Lajiki & MI026-13 & 3,701 & 36,000 & 18800 & 54800 & 166545 & 111745 & 2.039 \\
& MII24-31 & 4,519 & 36,000 & 18800 & 54800 & 203355 & 148555 & 2.711 \\
& Farmer & 3,101 & 36,000 & 18800 & 54800 & 139545 & 84745 & 1.546 \\
Arandun & 2010TZE -Y-DT & 4,011 & 36,000 & 18200 & 54200 & 180495 & 126295 & 2.330 \\
& - STR & & & & & & & \\
& 2009DTE-Y- & 4,252 & 36,000 & 18200 & 54200 & 191340 & 137140 & 2.530 \\
& STR & & & & & & & \\
& Farmer & 4,417 & 36,000 & 18200 & 54200 & 198765 & 144565 & 2.667 \\
Omupo & 2010TZE -Y-DT & 3,829 & 36,000 & 17400 & 53400 & 172305 & 118905 & 2.227 \\
& - STR & & & & & & & \\
& 2009DTE-Y- \\
STR & 3,187 & 36,000 & 17400 & 53400 & 143415 & 90015 & 1.686 \\
& Farmer & 2,518 & 36,000 & 17400 & 53400 & 113310 & 59910 & 1.122 \\
\hline
\end{tabular}

Source: Data collection 2014

*Family labour cost was not assigned cost but similar labour time was used on each variety. 
AYINDE O. E., et al.

\section{Profitability of On-farm Trial}

The result of the profitability of on-farm trial of the women farmers groups is presented in Table 3. The result shows that, at Isanlu Isin, the 2013TZEE-WDT STR variety gave the highest yield $(2,971 \mathrm{~kg} / \mathrm{ha})$, highest profit of eighty thousand, ninety five naira ( $\$ 80,095)$ and highest returns to investment of $149 \%$. This implies that for every one naira spent, one naira, forty nine kobo (1.49) was gained as returns. At Lajiki, the MII24-31 variety produced the highest yield $(4,519 \mathrm{~kg} / \mathrm{ha})$, highest profit of one hundred and forty eight thousand, five hundred and fifty five Nauru ( $\$ 148,555)$ and the highest $(271 \%)$ returns to investment. This implies that the farmers will gain two naira, seventy one kobo ( 2.71) for every one naira spent. At Arandun, it was different, with the farmers' variety producing the highest yield of $4,417 \mathrm{~kg} / \mathrm{ha}$ and the highest profits of one hundred and forty four thousand, five hundred and sixty five naira ( $\$ 144,565)$ and the highest returns to investment of $266 \%$. This implies that for every one naira used, a return of two naira, sixty six kobo ( $\$ 2.66)$ was gained. At Omupo, the 2010TZE -Y-DT - STR variety produced the highest yield of 3,829 $\mathrm{kg} / \mathrm{ha}$ and gave the highest profit of one hundred and eighteen thousand, nine hundred and five naira ( $\$ 118,905)$ and highest returns to investment of $222 \%$. This implies that about two naira twenty two kobo ( $\$ 2.22)$ was gained for every one naira used for production. This implies that, except at Arandun the DT maize varieties had better yield and higher profitability for the on-farm trial. This is expected as the DT maize variety is expected to perform better than the farmer's variety. This may be due to the ability of the variety to withstand drought condition and produce better yield of maize.

\section{CONCLUSION AND RECOMMENDATIONS}

It is evident that women farmers can be instruments of effective adoption and it is possible to conceive an integrated innovation in which women interest will be considered. It is therefore recommended that women farmers should be encouraged through increased access to agricultural inputs and innovations. This will increase the profitability of their production. Furthermore, efforts should be made to involve women farmers in the varietal selection procedure so as to facilitate easy adoption of the drought tolerant maize. This will ensure that the women farmers' needs and preferences are incorporated in the development of agricultural innovations. In addition, the women are more concerned with the food security of their family and hence they are important in innovation that improves the food security of farming households. It is therefore imperative that programmes and policies should not exclude female farmers.

Finally, the study recommends that information and knowledge on new technology and innovation should be made available to the women farmers. Supply of inputs of the innovative facilities should be evenly distributed among genders in order to achieve sustainable agricultural innovation and development.

\section{REFERENCES}

1. Olarinde, L. O., Manyong, V. M. and Akintola J. O. Attitudes Towards Risk Among Maize Farmers in The Dry Savanna Zone of Nigeria: Some Prospective Policies for Improving Food Production. African Journal of Agricultural Research 2 (8):399408, 2007

2. Soulé, B. G., Balami, D. and Blein, R. Nigeria's Cereal Economy, Regional Seminar on the Development of Cereal Commodity Chains in West Africa. Thematic Paper No. 2, 2009.

3. Ayinde, O. E., Abduolaye, T., Olaoye, G. and Akangbe J. A., Gender and Innovation in Agriculture: A Case Study of Farmers' Varietal Preference of Drought Tolerant Maize in Southern Guinea Savannah Region of Nigeria Albanian Journal of Agricultural Science, 12 (4): 617- 625, 2013.

4. FAOSTAT. Maize Yield, Retrieved fromhttp://faostat.fao.org/June 20, 2015.

5. Regier, G. Impact of Genetically Modified Maize on Risk, Output and Cost among Smallholders in South Africa, An Msc. Thesis Submitted to the Department of Agricultural Economics, College of Agriculture, Kansas State University Manhattan, Kansas, 2012.

6. Kostandini, G., Mills B. and Omamo, W., Ex-Ante Analysis of the Benefits of Transgenic Drought Tolerance Research on Cereal Crops in Low-Income Countries. Selected Paper prepared for presentation at the American Agricultural EconomicsAssociation Annual Meeting, Portland, July 29-August 1, 2007

7. Fukuda-Parr, Sakiko (2007). The Gene Revolution, GM crops and Unequal Development. London, Sterling, VA: Earthscan, 2007.

8. Garg, A. K., Kim, J. K., Owens, T. G., Ranwala, A. P., Choi, Y. D., Kochian, L. V. and R. J. Wu., Trehalose, Accumulation in 
AYINDE O. E., et al.

Rice Plants Confers High Tolerance Levels to Different Abiotic Stresses. Proceedings of the National Academy of Sciences, USA, 15898-15903, 2002.

9. FAO (2010a) Roles of Women in Agriculture. Prepared by the SOFA team and Cheryl Doss, Rome.

10.Godwin R. Crop Productivity Differentials between Male and Female Managed Farms in Kwara State, Nigeria. An Msc. thesis Submited to the Department of Agricultural Economics and Farm Management, Faculty of Agriculture, University of Ilorin, Kwara State, 2014.

11.Enter, A. A. and Amusa T. A. Determinants of Women's Contribution to Farming Decisions in Cocoa Based Agroforestry Households of Ekiti State, Nigeria, 4, 2010

12.Ayinde, O.E.,Muchie, M., Adewumi, M. O., and Abaniyan, E.O., Risk Analysis of Gender in Innovation System: A Case Study of Production of Downy Mildew Maize Resistant Variety in Kwara State, Nigeria. Obeche Journal. 30(1): 459-465, 2012.

13.Sagar, A., Technological Innovation, 2013, Retrieved from http://www.eoearth.org/view/article/156452 on 3rd July, 2015

14.Rogers, E. M., Diffusion of Innovations. 4th Edition. New York: The Free Press, 1995.
15.European Commission, Agricultural Technological Innovation, Joint Research Center, 2014, Retrieved from https//ec.europa.eu/ on $3^{\text {rd }}$ July, 2015

16. Wright, B. D. and Shih, T. M., Recent Developments and Challenges in Agricultural Innovation NBER Working Paper 15793, 2010.

17.Ighomereho O. S., Agbalajobi, T. D., Edegwa, K. S., Gender Influence on Access to Innovation Resources in Nigeria International Journal of Humanities and Social Science 3(1):216 - 227, 2013.

18. World Farmers' Organization, The Role of Women in Agriculture. 2013, Retrieved from www.wfo-oma.com/women in agriculture on 3rd July, 2015

19.Beuchelt T. D. and Badstue L. Gender, Nutrition- and Climate-Smart Food Production: Opportunities and Trade-offs Food Security 5:709-721, 2013

20.CIMMYT, Can Men and Women Benefit Equally from Agricultural Innovation? 2013, Retrieved from www.cimmyt.orgon $3^{\text {rd }}$ July 2015

21.Food and Agriculture Organization of the United Nations, The State of Food and Agriculture 2010-2011: Women in Agriculture: Closing the Gender Gap for Development (Rome, 2011).

22. World Bank, World Development Report 2012, Washington DC. 